\title{
Evaluation of the effectiveness and cost of different hormones in stimulating the spawning of thin lipped grey mullet, Liza ramada
}

\author{
Original \\ Article \\ Mostafa A. Mousa, Mohamed F. Kora and Noha A. Khalil \\ Fish Reproduction Laboratory, National Institute of Oceanography and Fisheries, Alexandria, \\ Egypt
}

\begin{abstract}
Introduction: It is known that mullets are not fully mature in captivity and therefore do not lay eggs. Therefore, hormonal preparations should be used to stimulate spawning.

Aim of the work: To evaluate the effectiveness and cost of using different types of hormones; pituitary hormone of carp, human chorionic gonadotropin, gonadotropin - releasing hormones in stimulating spawning of Liza ramada.

Materials and Methods: In this study, the pituitary gland was selected for two types of carp; common carp, silver carp, and human chorionic gonadotropin, as well as buserelin acetate and triptorelin acetate to stimulate the spawning of Liza ramada. In this regard, these hormones were tested on the rate of ovulation, fertilization rate, embryonic development and hatching rate, as well as an economic evaluation of the cost of injecting these hormones.

Results: The results showed the effectiveness of the used hormones to stimulate ovulation, fertilization and hatching, but at different rates. The use of the pituitary gland of silver carp induced a higher ovulation rate than those of common carp and human chorionic gonadotropin. Buserelin acetate induced higher ovulation, fertilization and hatching rates than those of triptorelin acetate. From the economic point of view, the use of the pituitary gland of silver carp as a stimulant dose and also the use of buserelin acetate as a resolving dose is less expensive compared to the use of other tested hormones.

Conclusion: The use of the pituitary gland of silver carp and buserelin acetate was effective to stimulate the spawning of mullets and less expensive.
\end{abstract}

Received: 09 April 2018, Accepted: 15 June 2018

Key Words: Economic efficiency, hormone, Liza ramada, spawning.

Corresponding Author: Mostafa A. Mousa, Fish Reproduction Laboratory, National Institute of Oceanography and Fisheries, Alexandria, Egypt, Tel.: 01001082930,E-mail: mostafa_mousa2002@yahoo.com.

ISSN: 1110-0559, Vol. 41, No. 3

\section{INTRODUCTION}

Captive propagation of fishes is essential to meet the growing demands placed on finite fisheries resources. To this end, the aquaculture industry must find reliable and cost effective methods to spawn and culture species of interest. The reproduction of many fish species in hatcheries is impossible without the application of hormonal preparations ${ }^{[1-3]}$. Adult fish, especially the females, are generally unable to produce their gametes naturally under hatchery conditions. The most cost- and time-effective way to obtain ovulated eggs and sperm is stimulating the fish with hormones. Reproductive hormones have been used to stimulate reproductive processes and induce ovulation, spermiation and spawning. Among various reproductive hormones, pituitary gland (PG) or human chorionic gonadotropin (HCG) and gonadotropin releasing hormone (GnRHa) are commonly used for inducing gametogenesis and spawning in many fish species ${ }^{[1-3]}$. Further research is needed; in particular, optimal application protocols need to be determined for each species individually.
The mullets are euryhaline species spawning only in salty water but can also grow in brackish and fresh waters. Culture of mullets restricted to areas of Egypt where seed could be collected from the wild and distributed. Its production is still remaining restricted until the induced spawning techniques are developed. However mullets, in captivity, do not spawn naturally and show some degree of reproductive dysfunction ${ }^{[4-6]}$. The inability of fish in captivity to complete its reproductive cycle is most likely due to a failure at one or more sites along the hypothalamohypophyseal-gonadal axis ${ }^{[7]}$. The failure of captive mullet fish to undergo final oocyte maturation (FOM) is thought to be caused by the shortage of gonadotropin synthesis $^{[5]}$ and/or the lack of pituitary gonadotropin $(\mathrm{GTH})$ release $^{[8]}$ at the end of vitellogenesis process. Under natural conditions, dopamine inhibits the action of GnRH and the release of GTHs through a feedback mechanism. Removing inhibitory effect of dopamine by antidopamines such as metoclopramide (MET) resulted in oocyte maturation and ovulation of grey mullet, implying the serious inhibitory effects of dopamines in the fish ${ }^{[9]}$. 
Generally for mass fry production in finfish, the use of $\mathrm{GnRH}$ analogue in combination with dopamine antagonist (DA) was recommended for spawning induction ${ }^{[10]}$. Accordingly, co-treatment of carp pituitary extract or human chorionic gonadotropin and different analogs of GnRHa in combination with DA were adapted to induce spawning in fish ${ }^{[3,11-15]}$.

Lack of knowledge on the effectiveness and cost of using different types of hormones; pituitary hormone of carp, human chorionic gonadotropin, gonadotropinreleasing hormones combined with a dopamine antagonist in stimulating spawning of thin-lipped grey mullet (L. ramada). Therefore, the present study aimed to evaluate the efficacy and cost of the different injection protocols for stimulating oocyte final maturation, ovulation, spermiation and spawning in ripe spawners of thin-lipped grey mullet, reared in freshwater fish farms.

\section{MATERIALS AND METHODS}

\section{Study Site:}

This study was carried out at both of El-Serw Fish Research Farm and El-Matareyya Research Station in the period between 1st. January and 31st. December, 2017.

\section{Hormones and chemicals}

\section{The hormones employed were:}

- Carp pituitary glands (CPG): acetone - dried common carp (Cyprinus carpio) and silver carp (Hypophthalmichthys molitrix) pituitary glands which obtained from sexually mature donor fish.

- Human chorionic gonadotropin (HCG) "pregnyl" (Nile Co. for Pharmaceuticals, Cairo, ARE)

- Luteinizing hormone-releasing hormone agonist analogue (LH-RHa): Buserelin acetate (Glp-His-TrpSer-Tyr-Ser-tBu-Leu-Arg-Pro-NHEt) (Sigma, Steinheim, Hamburg, Seelze, Germany).

- Luteinizing hormone - releasing hormone agonist analogue (LH-RHa): Triptorelin Acetate (Pyr-His-Trp-SerTyr-D-Trp-Leu-Arg-Pro-Gly-NH $\mathrm{N}_{2}$ acetate salt) (Santa Cruz Biotechnology, Inc., Dallas, TX, USA)

- Dopamine antagonist: The water-soluble dopamine receptor antagonist: metoclopramide (Sigma, Steinheim, Hamburg, Seelze, Germany).

\section{Induction of spawning}

\section{Seawater acclimation:}

The present experiments were carried out during the natural spawning season of thin-lipped grey mullet. Mature fish of thin-lipped grey mullet obtained from El-Serw Fish Research Station (freshwater habitat). Based on spermiation of males and slightly distended abdominal condition of females sexes were identified.
Mature breeders, at least two-years-old, with total weights (600-750) $\mathrm{g}$ and total lengths $(30-40) \mathrm{cm}$, were collected alive, by draining water completely, during the spawning season (November to January) from culture ponds. There were 70 females and 140 males selected from the captured fish used in the spawning induction experiments.

The fish were anesthetized in a solution $(40 \mathrm{mg} / \mathrm{L})$ of clove oil (Sigma) before handling ${ }^{[16]}$. Mature females of thin-lipped grey mullet were selected on the basis of the presence of a soft, swollen abdomen and protruding genital papillae. The maturity and the oocyte diameters of the females were staged by obtaining in vivo biopsy of the ovary using a polyethylene cannula ${ }^{[17]}$. The females that were used possessed oocytes whose diameters were greater than $600 \mu \mathrm{m}$. The diameter of at least 25 of the largest oocytes was recorded from each fish, and the position of the germinal vesicle $(\mathrm{GV})$ was determined after clearing the cytoplasm for $10 \mathrm{~min}$ with a $1: 1: 1 \mathrm{v} / \mathrm{v}$ methanol:ethanol:acetic acid solution ${ }^{[18]}$. Ripe males, in which milt could be easily extruded, by gentle pressure on their bellies, were used. Selected breeders were acclimated in 2000-litre circular fiberglass tanks (10 fish/tank). In brief, fish were transferred to water 10\% salinity (for $12 \mathrm{~h}$ ) which gradually increased to $35 \%$ (for another $12 \mathrm{~h}$ ).

\section{The experimental design and the protocol of hormonal injection:}

Acclimated breeders were transferred to 500-litre fiberglass tanks equipped with constant running ozonated seawater $(35 \%)$ and aeration (Female +2 males/tank) for induction of spawning. The hormones were injected, at $1 \mathrm{ml} /$ $\mathrm{Kg}$, into the dorsal musculature of fish adjacent to the dorsal fin. The used doses were calculated empirically depending on a series of preliminary experiments determining the optimal dose. The males of each spawner were injected with the same doses of female. The experimental design and the protocol of hormonal injection ${ }^{[3]}$ as described below. Seven different injection protocols were used (10 females for each group):

Group 1: priming injection at a dose of 20,000 IU HCG/ $\mathrm{kg}$ body weight followed, $24 \mathrm{~h}$ later, by a resolving injection of $100 \mu \mathrm{g}$ triptorelin acetate $+5 \mathrm{mg}$ Metoclopramide $/ \mathrm{kg}$ body weight.

Group 2: priming injection at a dose of 20,000 IU $\mathrm{HCG} / \mathrm{kg}$ body weight followed, $24 \mathrm{~h}$ later, by a resolving injection of $4 \mu \mathrm{g}$ buserelin acetate $+5 \mathrm{mg}$ Metoclopramide/ $\mathrm{kg}$ body weight.

Group 3: priming injection at a dose of $20 \mathrm{mg}$ common $\mathrm{CPG} / \mathrm{kg}$ body weight followed, $24 \mathrm{~h}$ later, by a resolving injection of $100 \mu \mathrm{g}$ triptorelin acetate $+5 \mathrm{mg}$ Metoclopramide/kg body weight.

Group 4: priming injection at a dose of $20 \mathrm{mg}$ common $\mathrm{CPG} / \mathrm{kg}$ body weight followed, $24 \mathrm{~h}$ later, by a resolving injection of $4 \mu \mathrm{g}$ buserelin acetate $+5 \mathrm{mg}$ Metoclopramide/ $\mathrm{kg}$ body weight. 
Group 5: priming injection at a dose of $20 \mathrm{mg}$ silver CPG/kg body weight followed, $24 \mathrm{~h}$ later, by a resolving injection of $100 \mu \mathrm{g}$ triptorelin acetate $+5 \mathrm{mg}$ Metoclopramide/kg body weight.

Group 6: priming injection at a dose of $20 \mathrm{mg}$ silver $\mathrm{CPG} / \mathrm{kg}$ body weight followed, $24 \mathrm{~h}$ later, by a resolving injection of $4 \mu \mathrm{g}$ buserelin acetate $+5 \mathrm{mg}$ Metoclopramide/ $\mathrm{kg}$ body weight.

Group 7: The control group of fish received saline solution $(0.9 \% \mathrm{NaCl})$ only, without hormone addition.

\section{Tissue processing and histology:}

The fishes were anesthetized in a solution $(20 \mathrm{mg} / \mathrm{L})$ of clove oil (Sigma) before handling ${ }^{[16]}$ and then perfused via the ascending aorta with $20 \mathrm{ml}$ of normal saline, followed by $50 \mathrm{ml}$ of Bouin's fluid at $4^{\circ} \mathrm{C}$. The gonads were removed and post fixed in Bouin's fluid for $24 \mathrm{~h}$ at $4^{\circ} \mathrm{C}$. The fixed gonads were thereafter dehydrated through graded ethanol solution, cleared and embedded in paraplast (M.P: $56-58{ }^{\circ} \mathrm{C}$ ). Consecutive transverse sections of the gonads $(4 \mu \mathrm{m}$ thickness) were stained with Harris's alum hematoxylin ${ }^{[19]}$ and aqueous solution of eosin as a counter stain.

\section{The response of ripe spawners and hormone cost during the induction of spawning:}

Hormone treatments were evaluated using the following criteria: (i) egg production, (ii) number of fertilized eggs and (iii) number of hatched larvae. The eggs were collected from each spawning tank (10 tanks) approximately two hours after the estimated time of spawning. Eggs were collected with PVC (polyvinyl chloride) pipes and siphoned into a plastic circular egg-collection basket (10 litres) with nylon bottom (mesh size $200 \mu \mathrm{m}$ ). The volume of total eggs was estimated by cylinder. Number of ovulated eggs produced by each female was estimated by eggs $\mathrm{ml}^{-1}$ egg volume multiplying by total eggs volume, and then the number of eggs $\mathrm{g}^{-1}$ body weight was observed for each female. Three replicates of 500 eggs from each fish were randomly taken and used to estimate number of fertilized eggs and number of hatched larvae. Fertilization was determined under a dissecting microscope approximately $1 \mathrm{~h}$ after spawning when eggs were at the cleavage stage. The hormone cost, per each kilogram of spawner body weight, was determined for each hormonal protocol injection. Also, the hormone cost, per each produced 100000 fertilized eggs, was calculated.

\section{Statistical analysis:}

Differences between treatments were tested by oneway ANOVA using the treatment as factor of variance. Statistical significance was accepted at $P<0.05$.

\section{RESULTS}

L. ramada females attained to prespawning stage in freshwater ponds. Furthermore, the fresh water was suitable for full maturation of $L$ ramada males; which attained to ripe stage in freshwater ponds. The oocytes of prespawning females were in vitellogenic stage (tertiary yolk stage) with a centrally located germinal vesicle (GV) (Figs. 1 and 2).

\section{Induced spawning and response of $L$. ramada to different injection protocols:}

Freshwater $L$. ramada breeders were successfully acclimated to seawater (35\%) prior to hormonal injection. As described in table (1), seven different injection protocols were used to stimulate oocyte final maturation, ovulation, spermiation and spawning in ripe spawners of thin-lipped grey mullet. The body weight of injected breeders was ranged from $640 \pm 40$ to $670 \pm 60 \mathrm{gm}$.

All injected breeders (groups; 2-6) were spawned (43- 46) $\mathrm{h}$ after the first injection (Table 1). But the breeders of group 1 injected protocol (injected with pregnyl; $\mathrm{HCG}$ as priming injection at a dose of $20,000 \mathrm{IU} / \mathrm{kg}$ body weight followed, $24 \mathrm{~h}$ later, by resolving injection of $100 \mu \mathrm{g}$ triptorelin acetate $+5 \mathrm{mg}$ Metoclopramide/ $\mathrm{kg}$ body weight), gave a spawning rate of $90 \%$ after $48 \mathrm{~h}$ from the first injection as illustrated in table (1). However, the breeders of group 7 (control) was not spawned.

The ovulated eggs were free, pelagic and transparent and vary in diameter between 0.9 and $1.0 \mathrm{~mm}$ (Fig. 3). The fertilized eggs have more than one oil globule, depending on the type and the dose of hormone; first cleavage begins at approximately $40 \mathrm{~min}$ (Fig. 4). The blastodisc was situated on the bottom side of the floating egg (Figs. 3 and 4). Forty-four hours after the spawning, lens fully formed; pigmentation gets dark and various colour combinations noticed (Fig. 5). The embryonic development was completed and hatching occurred at 48:00 h after spawning. The body of a newly hatched larva remained curved for several hours after hatching. The larva had a large oval-shaped yolk sac with an oil droplet at its posterior end. The mouth and anus were not yet open. No pigmentation was recognized over the yolk (Fig. 6).

In general, the use of carp pituitaries as a priming injection at a dose of $20 \mathrm{mg} / \mathrm{kg}$ body weight gave a higher rate of ovulation than using of pregnyl. Furthermore, the pituitary glands of silver carp were more effective in inducing oocyte final maturation, ovulation, spermiation and spawning; since the number of ovulated eggs was significantly higher than those produced by using pregnyl and common carp pituitary glands as shown in table (1). The addition of $4 \mu \mathrm{g}$ buserelin acetate $+5 \mathrm{mg}$ Metoclopramide $/ \mathrm{kg}$ body weight as a resolving injection, in groups 2, 4 and 6, significantly increased the number of ovulated eggs $(113 \pm 17 ; 155 \pm 12$ and $169 \pm 21$ respectively) in comparison with the use of $100 \mu \mathrm{g}$ triptorelin acetate + $5 \mathrm{mg}$ Metoclopramide/ $\mathrm{kg}$ body weight in groups 1,3 and $5(105 \pm 13 ; 143 \pm 14$ and $159 \pm 19$, respectively) as indicated in table (1).

The number of fertilized eggs followed the same 
manner as the number of ovulated eggs in the different injection protocols; since the use of carp pituitary glands as a priming dose followed by buserelin acetate gave a higher values $(29 \pm 5,46 \pm 5$ and $54 \pm 5$ for groups 2,4 and 6 , respectively) than those used the pregnyl followed by triptorelin acetate $(25 \pm 3 ; 40 \pm 6$ and $47 \pm 6$ for groups 1,3 and 5 respectively). Similarly, the number of hatched larvae in buserelin acetate groups $(15 \pm 4 ; 23 \pm 4$ and $28 \pm 6$ for groups 2, 4 and 6 respectively) was significantly higher than those in triptorelin acetate groups $(12 \pm 3 ; 20 \pm 3$ and $24 \pm 5$ for groups 1,3 and 5 respectively) as shown in table (1).

The use of carp pituitary glands as a priming dose followed by buserelin acetate as a resolving injection minimizes the cost of hormone injection (Egyptian Pound)/ kg body weight and consequently the production cost of 100000 fertilized eggs (table 1).

Table 1: The response of $L$. ramada ripe spawners to hormonal treatment and hormone cost during the induction of spawning

\begin{tabular}{|c|c|c|c|c|c|c|c|c|}
\hline \multirow[t]{2}{*}{ Spawned group } & \multirow[t]{2}{*}{ Body weight } & \multicolumn{5}{|c|}{ Response of ripe spawners to hormonal treatment } & \multicolumn{2}{|c|}{ Hormone cost } \\
\hline & & $\begin{array}{c}\text { Spawning } \\
\text { rate }(\%)\end{array}$ & $\begin{array}{l}\text { Time of } \\
\text { spawning } \\
\text { after 1st } \\
\text { injection } \\
\text { (h: min) }\end{array}$ & $\begin{array}{c}\text { Number of } \\
\text { ovulated } \\
\text { eggs } \\
\left(\mathrm{x} \mathrm{g}^{-1} \text { fish) }\right.\end{array}$ & $\begin{array}{c}\text { Number of } \\
\text { fertilized } \\
\text { eggs } \\
\left(\mathrm{x} \mathrm{g}^{-1} \text { fish }\right)\end{array}$ & $\begin{array}{c}\text { Number } \\
\text { of hatched } \\
\text { larvae } \\
\left(\mathrm{x} \mathrm{g}^{-1} \text { fish }\right)\end{array}$ & $\begin{array}{c}\text { Hormone } \\
\text { cost } / \mathrm{Kg} \\
\text { body weight } \\
\text { (Egyptian } \\
\text { Pound) }\end{array}$ & $\begin{array}{l}\text { Hormone } \\
\text { cost per } \\
100000 \text { of } \\
\text { fertilized } \\
\text { eggs } \\
\text { (Egyptian } \\
\text { Pound) }\end{array}$ \\
\hline Group 1 & $650 \pm 36$ & $90^{\mathrm{a}}$ & $48: 00^{\mathrm{a}}$ & $105 \pm 13^{\mathrm{a}}$ & $25 \pm 3^{\mathrm{a}}$ & $12 \pm 3^{\mathrm{a}}$ & $600^{\mathrm{a}}$ & $2400^{\mathrm{a}}$ \\
\hline Group 2 & $640 \pm 40$ & 100 & $46: 30^{\mathrm{b}}$ & $113 \pm 17^{\mathrm{b}}$ & $29 \pm 5^{\mathrm{b}}$ & $15 \pm 4^{\mathrm{b}}$ & $520^{\mathrm{b}}$ & $1793^{\mathrm{b}}$ \\
\hline Group 3 & $660 \pm 52$ & 100 & $46: 00^{\mathrm{b}}$ & $143 \pm 14^{c}$ & $40 \pm 6^{c}$ & $20 \pm 3^{c}$ & $650^{\mathrm{c}}$ & $1625^{\mathrm{c}}$ \\
\hline Group 4 & $646 \pm 38$ & 100 & $45: 00^{c}$ & $155 \pm 12^{\mathrm{d}}$ & $46 \pm 5^{\mathrm{d}}$ & $23 \pm 4^{\mathrm{d}}$ & $570^{\mathrm{d}}$ & $1239^{\mathrm{d}}$ \\
\hline Group 5 & $655 \pm 45$ & 100 & $44: 00^{\mathrm{c}}$ & $159 \pm 19^{d}$ & $47 \pm 6^{\mathrm{d}}$ & $24 \pm 5^{\mathrm{d}}$ & $550^{\mathrm{d}}$ & $1170^{\mathrm{d}}$ \\
\hline Group 6 & $657 \pm 55$ & 100 & $43: 15^{\mathrm{d}}$ & $169 \pm 21^{\mathrm{e}}$ & $54 \pm 5^{\mathrm{e}}$ & $28 \pm 6^{\mathrm{e}}$ & $470^{\mathrm{e}}$ & $870^{\mathrm{e}}$ \\
\hline Group 7 & $670 \pm 60$ & No spawning & - & - & - & - & - & - \\
\hline (Control) & & & & & & & & \\
\hline
\end{tabular}

Data are reported as means $\pm \mathrm{SD}$.

Significantly different means $(\mathrm{P}<0.05)$ are indicated by different letters (Tukey's test). 


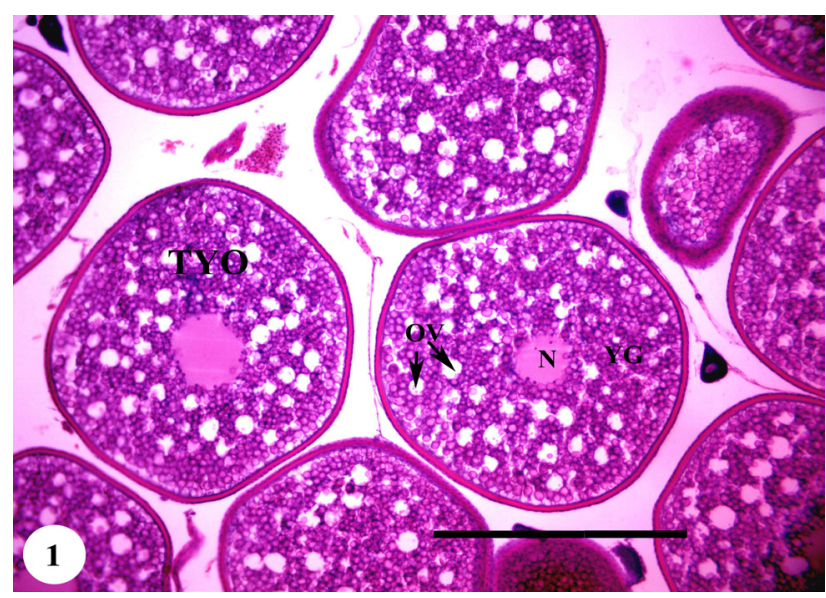

Fig. 1: Transverse sections of ovaries of $L$. ramada, stained with Harris's hematoxylin and eosin, showing ovary of postvitellogenic female before injection of hormones at tertiary yolk oocyte (TYO) which has central-located nucleus (N), ooplasm impregnated with yolk globules (YG) and lesser number of oil vesicles $(\mathrm{OV})$ distributed in the ooplasm. Scale bar $=500 \mu \mathrm{m}$.

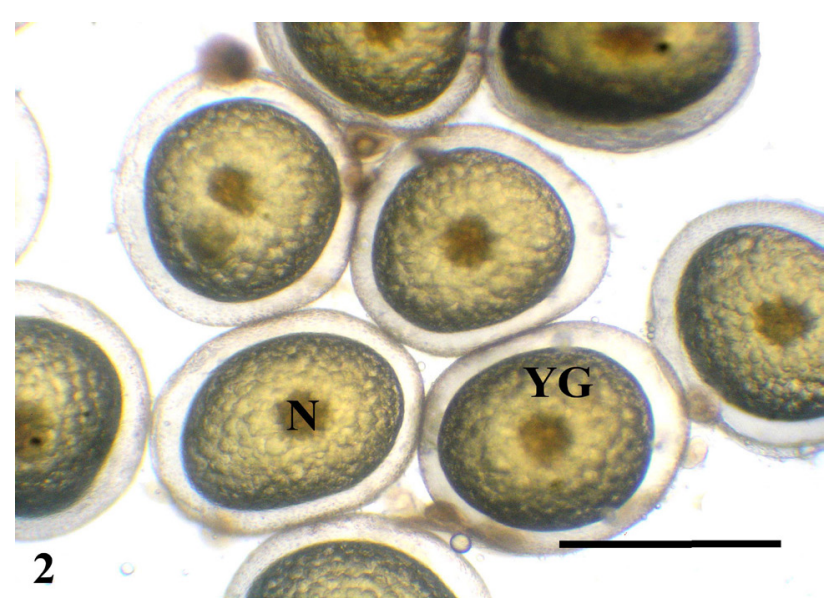

Fig. 2: Macroscopic view of prespawning tertiary yolk oocytes which have central-located nucleus $(\mathrm{N})$, ooplasm impregnated with yolk globules (YG). Scale bar $=500 \mu \mathrm{m}$.

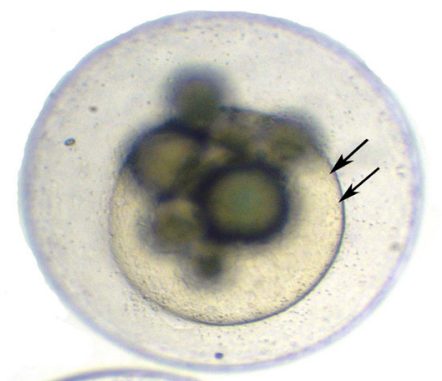

3

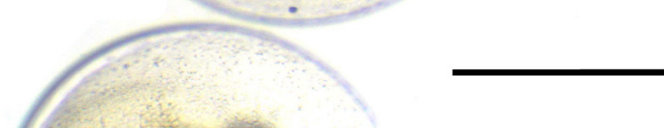

Fig. 3: Macroscopic view of ovulated eggs with blastodisc situated on the bottom side of the floating egg (arrows). Scale bar $=500 \mu \mathrm{m}$.

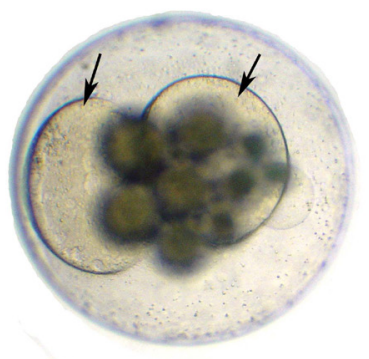

4

Fig. 4: Macroscopic view of fertilized eggs at Two-cell stage (arrows). Scale bar $=500 \mu \mathrm{m}$.

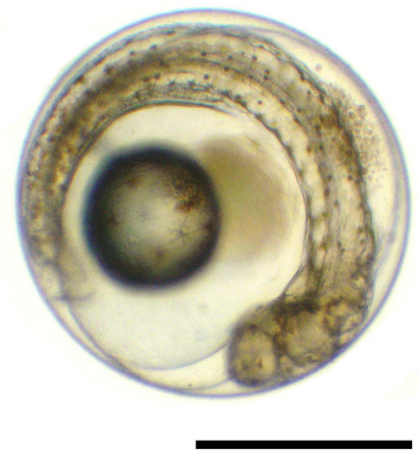

5

Fig. 5: Macroscopic view of developed embryo at $44 \mathrm{~h}$ post fertilization; lens fully formed; pigmentation gets dark and various colour combinations noticed. Scale bar $=500 \mu \mathrm{m}$.

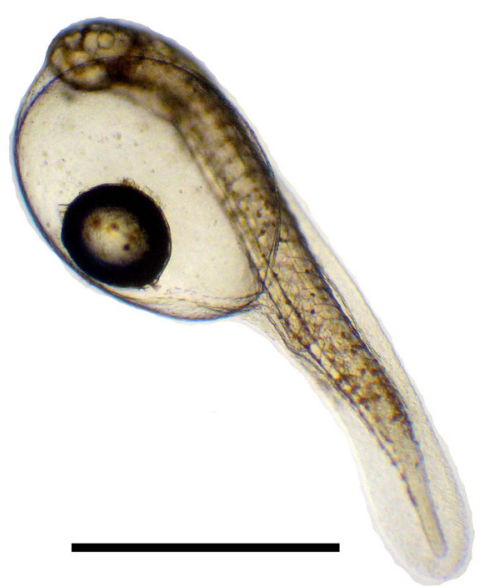

Fig. 6: Macroscopic view of hatched larvae exhibiting a large oval-shaped yolk sac with an oil droplet at its posterior end. The mouth and anus were not yet open. Scale bar $=1000 \mu \mathrm{m}$. 


\section{DISCUSSION}

In the present study, injection of pituitary extracts and HCG in combination with LH-RHa and dopamine antagonist (metoclopramide) induced the final stages of maturation, ovulation and spawning in L. ramada. Understanding the coordination between environmental factors and the fish internal regulating factors is very important for successful reproduction of fish. Mullets do not spawn spontaneously when reared in captivity. Failure of captive mullets to undergo FOM, without hormonal injection, is thought to be caused by the shortage of gonadotropin synthesis ${ }^{[4-6]}$. GnRHa and HCG act at different endocrine levels to induce oocyte maturation and ovulation, and this may explain the different results observed ${ }^{[20-22]}$. Both gonadal and extragonadal hormones are rather equally essential for the induction of circadian ovarian cycle of the grey mullet $^{[23]}$. Exogenous GTH preparations acts directly at the level of the gonad, and LH-RHa release the endogenous GTH stores from pituitary. Endogenous GTH, in turn, acts at the level of the gonad to induce steroidogenesis and the process of ovulation and spermiation. In this work, we used pituitary extracts $(20 \mathrm{mg} / \mathrm{kg}$ body weight $)$ or HCG (20000 IU/ kg body weight) as priming injection. Alike, previous investigators used $\mathrm{HCG}$ and pituitary glands successfully for the induction of ovulation and spawning in a number of fishes ${ }^{[24-31]}$.

A large number of synthetic analogues of the native peptide were prepared to develop both long-acting superactive analogues (agonists) and inhibitory analogues (antagonists). The classic action of GnRH-I agonists that have been chemically synthesized is to augment efficacy (half-life), potency and binding to the receptor were compared to native GnRH-I ${ }^{[32]}$ whereas two types of super-active agonists revealed. The first was decapeptides (GnRHa-I) like triptorelin, and the second was nonapeptides (GnRHa-II) like buserelin ${ }^{[33]}$. Later, GnRH-I has become the major stimulator of gonadotropins and probably other pituitary hormones as well, whereas GnRHII functioned as neuromodulators, affecting reproductive behavior ${ }^{[34]}$. In the present study, the pituitary gland for two types of carp; common carp, silver carp, and human chorionic gonadotropin, as well as buserelin acetate and triptorelin acetate was selected to stimulate the spawning of Liza ramada. The results showed the effectiveness of the used hormones to stimulate ovulation, fertilization and hatching, but at different rates. The use of the pituitary gland of silver carp has given higher ovulation rate than those of common carp and the human chorionic gonadotropin. In several fish species, combined treatment of a synthetic analogue of $\mathrm{GnRH}$ and a dopamine inhibitor has been effective tool for overcoming reproductive dysfunction and obtaining good quality eggs in captivity ${ }^{[1-15,35-37]}$. The combination of gonadotropin-releasing hormone analogue
(GnRHa) and dopamine (DA) antagonists is not only beneficial, but also necessary for ovulation induction in teleosts. In the present study, GnRHa (Buserelin) $5 \mu \mathrm{g} \mathrm{kg}^{-1}$ BW in combination with DA antagonist (Metoclopramide; $5 \mathrm{mg} \mathrm{kg}^{-1} \mathrm{BW}$ ) could be effective for spawning induction in mullets. Similarly, GnRHa (Buserelin) $5 \mu \mathrm{g} \mathrm{kg}^{-1} \mathrm{BW}$ in combination with DA antagonists or/and adrenergic agonist was effective for spawning induction in Rutilus frisii kutum $^{[15]}$. Alike, other researchers have reported that GnRHa (Buserelin) alone and in higher doses was more effective in ovulation and spawning induction ${ }^{[38,39]}$.

The present results indicated that Buserelin acetate gave higher ovulation, fertilization and hatching rates than those of triptorelin acetate. The ultimate goal of hormone administration in captive reproduction of fishes is induction of FOM and ovulation, leading to either successful volitional spawning or manual stripping. Thin-lipped grey mullet in spawning experiments were given 43-48 hour window to volitionally release any ovulated eggs after which they were manually stripped. Analysis of spawning success indicated that Buserelin was effective for spawning induction in $L$. ramada at shorter latency period ( $43 \mathrm{~h}$ ) than for Triptoreline. The effects of hormone induced spawning on egg quantity and quality are important considerations in determination of appropriate hormone dosage regimes. $L$. ramada females injected with Buserelin produced significantly more ovulated eggs $(169 \pm 21)$ and fertilized eggs $(54 \pm 5)$ per gram body weight than females injected with Triptoreline. Buserelin was effective for spawning induction in a number of fishes ${ }^{[15,38-40]}$. Also, [D-Trp6] GnRH (Triptoreline, Decapeptyl) has been successfully used to induce final maturation and synchronize ovulation of some fish ${ }^{[41]}$.

From the economic view point, the use of the pituitary gland of silver carp as a stimulant dose and also the use of Buserelin as a resolving dose is less expensive compared to the use of other tested hormones.

\section{CONCLUSION}

The number of ovulated eggs, fertilized eggs and hatched eggs were higher in buserelin acetate spawned fish than Triptoreline. Therefore this research recommends the use of the pituitary gland of silver carp and buserelin acetate in combination with Metoclopramide for effective low cost stimulation of spawning of mullets.

\section{ACKNOWLEDGEMENT}

We are extremely grateful to Professor Shaaban Mousa (Department of Anaesthesiology, Charite University Medicine Berlin, Germany) for critical review of the manuscript. 


\section{CONFLICT OF INTEREST}

There are no conflicts of interest.

\section{REFERENCES}

1. Austriano JF, Mrco-Jimenez F, Perez L, Balasch S, Garzon DL, Penaranda DS, Vicente JS, Viudes-de-Castro MP, Jover M. Effect of HCG as spermiation inducer on European eel semen quality. Theriogenology (2006) 66: 1012-1020.

2. Mehdi Y, and Ehsan MS. A review of the control of reproduction and hormonal manipulations in finfish species. African Journal of Agricultural Research (2011) 6 (7): 1643-1650.

3. Mousa MA. Induced spawning and embryonic development of Liza ramada reared in freshwater ponds. Animal Reproduction Science (2010) 119: 115-122.

4. Mousa MA. Biological studies on the reproduction of mullet (Mugil cephalus L.) in Egypt. Ph.D. Thesis. Ain Shams University (1994) 278 pp.

5. Mousa SA, Mousa MA. Immunocytochmical studies of the gonadotropic cells in the pituitary gland of female mullet, Mugil cephalus during the annual reproductive cycle in both natural habitat and captivity. J Egypt Ger Soc Zool (1997) 23 (c): 1736.

6. Mousa MA, El-Gamal AE. Experimental study on the ovarian development and the gonadotropic cell activity in thin-lipped grey mullet, Liza ramada (Risso) in captivity. J Egypt Ger Soc Zool (1999) 30 (c): 51-65.

7. Zohar Y, Mylonas CC. Endocrine manipulations of spawning in cultured fish: From hormones to genes. Aquaculture (2001) 197: 99-136.

8. Zohar Y. Fish reproduction: its physiology and artificial manipulation. In Fish Culture in Warm Water Systems: Problem and Trends (Shilo, M. and Sarig, S., eds) (1989) pp. 65119-. Boca Raton: CRC Press.

9. Aizen J, Meiri I, Tzchori I, Levavi-Sivan B, Rosenfeld $H$. Enhancing spawning in the grey mullet (Mugil cephalus) by removal of dopaminergic inhibition. Gen Comp Endocrinol (2005) 142: 212-221.
10. Nguyen T, Luc M, Nguyen D. Study on seed production of sand bass Psammoperca waigiensis (Cuvier and Valenciennes, 1828) in a research report under contract between the University of Fisheries and SUMA. Ministry of Fisheries, Hanoi, Vietnam (in Vietnamese) (2003).

11. Heyrati FP, Mostafavi H, Toloee H, Dorafshan S. Induced spawning of kutum, Rutilus frisii kutum (Kamenskii, 1901) using (DAla6, Pro9-NEt) GnRHa combined with domperidone. Aquaculture (2007) 265: 288-293.

12. Podhorec P, Kouril J. Induction of final oocyte maturation in Cyprinidae fish by hypothalamic factors: a review. Vet Med (2009) 54: 97-110.

13. El-Hawarry WN, Abd El-Rahman SH, Shourbela RM. Breeding response and larval quality of African catfish (Clarias gariepinus, Burchell 1822) using different hormones/hormonal analogues with dopamine antagonist. Egyptian Journal of Aquatic Research (2016) 42: 231-239.

14. Podhorec P, Socha M, Ammar IB, SokolowskaMikolajczyk M, Brzuska E, Milla S, Gosiewski G, Stejskal V, Simko M, Kouril J. The effects of GnRHa with and without dopamine antagonist on reproductive hormone levels and ovum viability in tench Tinca tinca. Aquaculture (2016) 465: 158-163.

15. Koohilai S, Oryan S, Sahafi HH, Mostafavi PG, Behzadi S. Ovulation and spawning induction in Caspian kutum Rutilus frisii kutum by administration of GnRHa and catecholaminergic pharmaceutical compounds with Ovaprim. Aquaculture Research (2016): 1-9.

16. Mousa MA. The efficacy of clove oil as an anaesthetic during the induction of spawning of thin-lipped grey mullet, Liza ramada (Risso). J Egypt Ger Soc Zool (2004) 45 (A): 515-535.

17. Shehadeh ZH, Kuo CM, Milisen K. Validation of an in vivo method for monitoring ovarian development in the grey mullet (Mugil cephalus). J Fish Biol (1973) 5: 489-496.

18. Crim LW, Glebe BD. Reproduction. In: C.B. Schreck and P.B. Moyle (ed.) Methods for Fish Biology, American Fisheries Society, Bethesda (1990) 529-554 pp.

19. Conn HJ. Biological stains. Baltimore: Williams 
and Wilkins Company (1953) 1-692 pp.

20. Lam TJ. Applications of endocrinology to fish culture. Can J Fish Aquat Sci (1982) 39: 111-137.

21. Swanson CP, Dickey JT, Campbell B. Biochemistry and physiology of fish gonadotropins. Fish Physiol Biochem (2003) 28: 53-59.

22. Yaron Z, Gur G, Melamed P, Rosenfeld H, ElizurA, Levavi-Sivan B. Regulation of fish gonadotropins. Int Rev Cytol (2003) 225: 132-187.

23. Das P, Pramanick K, Maity A, Maiti BR. The role of some extra-gonadal hormones on the circannual ovarian cycle of the flat head grey mullet, Mugil cephalus L. Biological Rhythm Research (2013) 44 (5): 830-843.

24. Guzmán JM, Ramos AG, Mylonas CC, Mananos E. Comparative effects of human chorionic gonadotropin (hCG) and gonadotropin-releasing hormone agonist (GnRHa) treatments on the stimulation of male Senegalese sole (Solea senegalensis) reproduction. Aquaculture (2011) 316: 121-128.

25. Goo IB, Park In-S, Gil HW, Im JH. Stimulation of Spermiation by Human Chorionic Gonadotropin and Carp Pituitary Extract in Grass Puffer, Takifugu niphobles. Dev Reprod (2015) 19 (4): 253-258.

26. Karim E, Hasan J, Hoq E. Hormone Induced Artificial Breeding of a Commercially Important Marine Finfish, Striped Mullet (Mugil cephalus L.) in Bangladesh. Turkish Journal of Fisheries and Aquatic Sciences (2016) 16: 135-140.

27. Panda S. A review on induced breeding in fishes. International Journal of Bioassays (2016) 5.5: 4579-4588

28. Zadmajid V. Comparative effects of human chorionic gonadotropin (hCG) and Ovaprim ${ }^{\mathrm{TM}}$ (sGnRHa + domperidone) on the reproductive characteristics of wild-caught male Longspine scraper, Capoeta trutta (Heckel, 1843). Aquaculture (2016) 463: 7-15.

29. Martins EFF, Streit Jr DP, Abreu JS, CorrêaFilho RAC, Oliveira CAL, Lopera-Barrero NM, Povh JA. Ovopel and carp pituitary extract for the reproductive induction of
Colossoma macropomum males. Theriogenology (2017) 98: 57-61.

30. Pereira TSB, Boscolo CNP, Moreira RG, Batlouni SR. The use of mGnRHa provokes ovulation but not viable embryos in Leporinus macrocephalus. Aquacult Int (2017) 25: 515-529.

31. Żarski D, Katarzyna Palińska-Żarska K, Łuczyńska J, Krejszeff S. The type of spawning agent affects the egg composition during outofseason spawning but not during in-season spawning in Eurasian perch, Perca fluviatilis. Gen Comp Endocrinol (2017) 245: 19-29.

32. Roberts JL, Mani SK, Woller MJ, Glucksman MJ, Wu, TJ.LHRH-(15-): a bioactive peptide regulating reproduction. TRENDS in Endocrinology and Metabolism (2008) 18: 386-392.

33. Schneider F, Tomek W, Gründker C Gonadotropin-releasing hormone $(\mathrm{GnRH})$ and its natural analogues: A review. Theriogenology (2006) 66: 691-709.

34. Schneider F, Tomek W, Brüssow KP. Chapter 4: Progress in research and application of gonadotropin-releasing hormone (GNRH) in animal reproduction. In: Animal Reproduction: New Research Developments. Editor: Lucas T. Dahnof (2009) Nova Science Publishers, Inc.

35. Kalbassi MR, Lorestani R, Marammazi JG. Improvement of Sperm Quality Indices of Benni Fish (Barbus sharpeyi) by Application of LHRHA2 and Metoclopramide. J Agr Sci Tech (2014) 16: 91-104.

36. Mohammadian T, Malekpouri P, Zare M, Zainodini MA. Effects of different spawning agents on serum levels of reproductive steroid hormones and cortisol level in adult female Barbus sharpeyi (Gunther, 1874). Fish Physiol Biochem, 2015: 1-15.

37. Mousa MA, Khalil NA, Hashem AM, Kora MF. Immunohistochemical study of gonadotropinreleasing hormone and somatolactin during induced spawning of Liza ramada. Egypt J Histol (2018) 40 (3): 303-314.

38. Arabaci M, Cagirgan H, Sari M. Induction of Spawning in Common Carp (Cyprinus carpio) using LHRHa ([DSer (tBu)6, Pro9-NEt]-LHRH) 
combined with Haloperidol: Effects of Different Treatment Time and Determination of Latency Period Dependence on Temperature. Turkish J Fish Aquat Sci (2001) 1: 1-5.

39. Sharaf S. Effect of GnRHa, pimozide and Ovaprim on ovulation and plasma sex steroid hormones in African catfish Clarias gariepinus. Theriogenology (2012) 77: 1709-1716.

40. Nascimento NF do, Silva RC da, Valentin FN, Paes M do CF, Marta Verardino De Stéfani MV De, Nakaghi LSO. Efficacy of buserelin acetate combined with a dopamine antagonist for spawning induction in the bullfrog (Lithobates catesbeianus). Aquaculture Research (2014): 1-4.

41. Marino G., Azzurro E., Finoia M.G., Messina M.T., Massari A., Mandich A. Recent advances in induced breeding of the dusky grouper Epinephelus marginatus (Lowe, 1834). Recent advances in Mediterranean aquaculture finfish species diversification. Zaragoza: CIHEAM, 2000. p. 215225- (Cahiers Options Méditerranéennes; n. 47). 
الملخص العربى

\section{تقييم فعالية وتكلفة الهرمونات المختلفة فى تحفيز تفريخ أسماك الطوبار}

\section{مصطفى عبد الوهاب موسى ، محمد فتحى قورة ، نهى عبد الحميد خليلى الحئ معمل تناسل وتفريخ الأسماك ، المعهد القومى لعلوم البحار والمصايد}

المقدمة: أن لا يكتمل النضج النهائي لأسماك العائلة البورية في الأسر فلا يتم وضع البيض إلا باستخدام التحضيرات الهرمونية لتحفيز التفريخ.

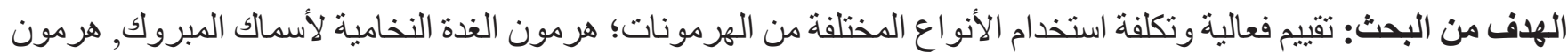

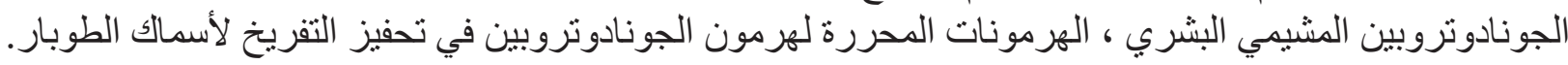

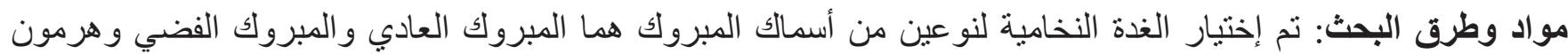

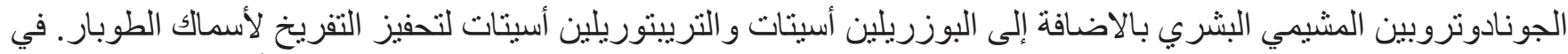

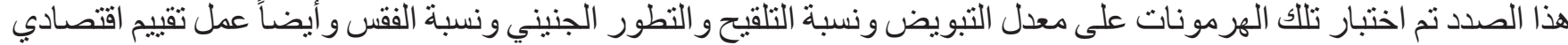
لتكلفة الحقن بتلك الهرمونات.

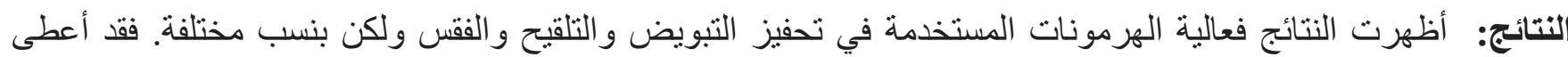

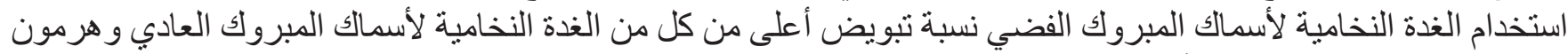

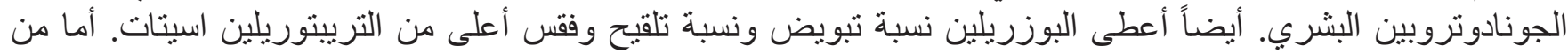

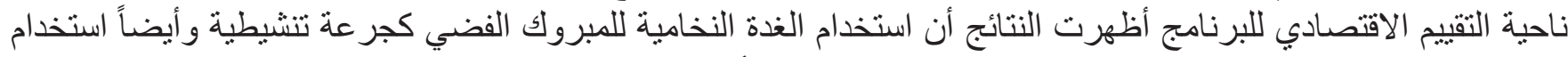

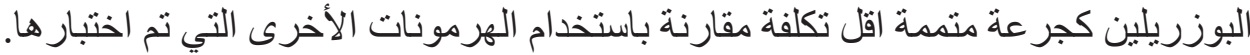

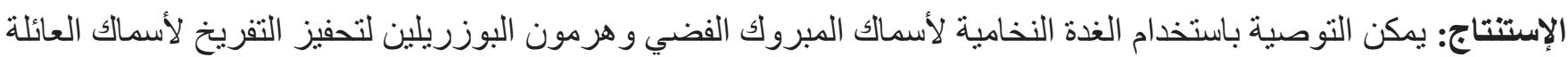
البورية حيث أنهما اكثر فاعلية و أقلى تكلفة. 